\title{
Solid-supported Synthesis of 3, 4-dihydrobenzo [2, 3-d] pyrimidines
}

\author{
A.D. Mishra \\ Prithvi Narayan Campus, Tribhuvan University, Pokhara, Nepal \\ e-mail: mishraad05@hotmail.com
}

\begin{abstract}
Different 3,4-dihydrobenzo[2,3-d] pyrimidine derivatives were synthesized by the condensation of substituted 1, 3cyclohexadienes and formamide, using inorganic solid supports under microwaves. Simple and commonly available compounds were used as starting materials in the reactions. The compounds were tested against different fungal and bacterial strains and found considerably effective.
\end{abstract}

Key words: inorganic solid supports, microwave, benzopyrimidines, environmentally benign, antimicrobial

\section{Introduction}

Benzopyrimidines have found application in a wide range of medicinal chemis-try because of their diverse biological activities, such as antibacterial (Tajudeen \& Khan 2007 and Abdel-galil \& Mohamad 2006), anticonvulsant (Pedro et al. 2006), anti-inflammatory (Ghorab \& Abdel-Hamide 1995, Reddy et al. 1999), antitumor (Ratham et al. 1990, Vyas et al. 2007) and antlfungal (Kumar et al. 1990) activities. These chemo-therapeutic applications of benzopyrimidine derivatives has drawn the concern to synthesize some novel substituted 3,4-dihydrobenzo[2,3d]pyrimidines (7a-j) by adopt-ing a new route under inorganic solid supported microwave irradiations.

Traditional methods reported (Sarvanan et al. 1998, Landure et al. 2002, Nair et al. 1986) for the synthesis of benzopyrimidi-ne derivatives suffer from drawbacks, such as longer re-action time, complicated workup, use of expensive and hazardous chemicals with low yield. The title compounds were synthesized in this study using commonly available reagents under dry media microwave irradiation to overcome the men-tioned drawbacks. Microwave assisted organic synthesis proceeds with facile reactions to provide high yield within a very short reaction time period (Gamal El-Hiti et al. 2000). This methodology also avoids the use of excess solvents and harmful acids or bases, which are generally used for the catalysis of the reactions (Dong \& Weik 2000, Berman \& Werbel 1991). Solution phase microwave organic reactions have some limitations, such as the possibility of super heating of the solvents which may result in serious explosions (Smith et al. 1996, Archana et al. 2002 , Caddick 1995). Microwave activated dry media synthesis on solid inorganic supports is the most efficient and ecofriendly technology (Varma \& Saini 1997). Reactions can be carried out easily at ambient pressure in open vessels by using even domestic microwave ovens (Kidwai \& Misra 1999).Moreover, the use of solid acid and base catalysts reduces the amount of toxic wastes and by-product formation (Kidwai et al. 1999).

Pharmaceutical interest in benzopyrimidines has insisted to synthesize a se-ries of new 3,4-dihydrobenzo[2,3d]pyrimidines $(7 \mathrm{a}-\mathrm{j})$ in dry media under micro-wave irradiations by the cyclization of 1,3-cyclohexadiene derivatives (6a-j) with formamide under acidic conditions (Scheme 1).

\section{Methodology}

The microwave reactions were carried out in a Kenstar Microwave Oven, Model No. OM9925E (2450 MHz, 800 $\mathrm{W})$ and the IR spectra were recorded on a Perkin Elmer FTIR-1710 spectrophotometer using $\mathrm{KBr}$ pellets. The ${ }^{1} \mathrm{H}$ NMR spectra were recorded on a FT NMR Hitachi R-600 $(60 \mathrm{MHz})$ instru-ment. Elemental analyses were performed using a Heraeus CHN-Rapid Analyser. The temperature of the reaction mixture was measured using an AZ, Mini Gun Type, non-contact IR thermometer, Model No. 8868. The melting points were determined on a Thomas 
Hoover melting point apparatus and are uncorrected. Chemical shifts, ä, for ${ }^{1} \mathrm{H}$ NMR are given in ppm relative to the internal reference, tetramethylsilane (TMS) and the IR frequencies, í , in $\mathrm{cm}^{-1}$ The purity of the compounds were checked on aluminium plates coated with silica gel (Merck).

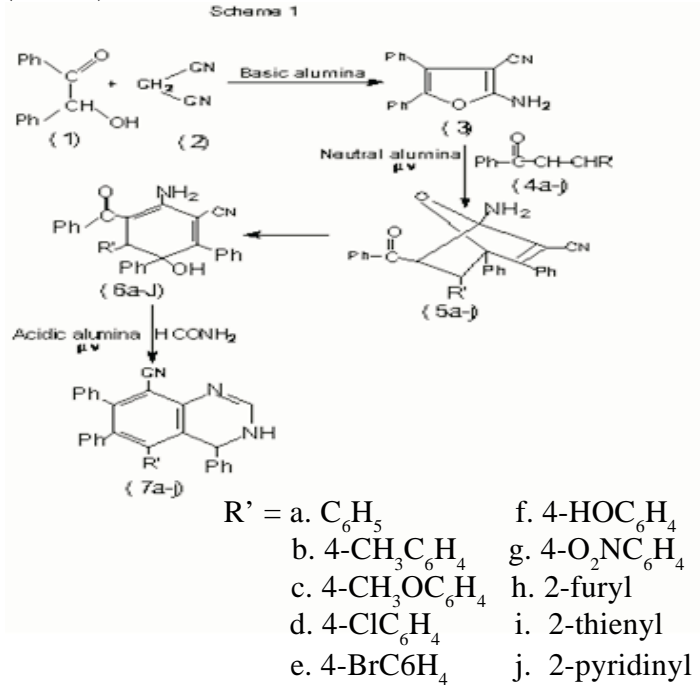

Synthesis of 2-amino-3-cyano-4, 5-diphenylfuran (3): This compound was synthesized using microwave technology based on a literature method (Loupy et al. 1994).

Synthesis of á, â -unsaturated ketones (4a-j):

These compounds were synthesized by a modified literature method (Moglai \& Reddy 2004).

General procedure for the synthesis of 6-substituted2-amino-1-benzoyl-3-cyano-5-hydroxy-4,5-diphenyl1,3-cyclohexadiene $(6 \mathrm{a}-\mathbf{j})$ :

Equimolar amounts (0.01 mol) of 2-amino-3-cyano-4,5diphenyl furan (3) and á,â-unsatu-rated ketone or chalcone ( $4 \mathrm{a}-\mathrm{j}$ ) were dissolved in $10 \mathrm{ml}$ of $\mathrm{EtOH}$. The solution was then adsorbed on 20 gm of neutral alumina or montmorillonite $\mathrm{K}_{10}$ clay or silica gel in a small beaker. The reaction mixture was dried in air and the beaker was put in an alumina bath inside the microwave oven and ir-radiated for 5-6 min. The progress of the reaction was monitored by TLC at intervals of $30 \mathrm{sec}$. The product (6a-j) was extracted into $\mathrm{EtOH}$ and obtained in the solid state after removal of the solvent by distillation under reduced pressure.

General procedure for the synthesis of 5-substituted8-cyano-4,6,7-triphenyl-3,4-dihydrobenzo[2,3d]pyrimidines (7a-j):
Conventional reactions (Method A): Thus obtained pure sample of 1,3-cyclohexadiene derivative (6a-j) in the amount of $0.01 \mathrm{~mol}$ was dis-solved in $10 \mathrm{ml}$ of formamide and $2 \mathrm{ml}$ of formic acid was also added to the solution, which was then refluxed under stirring for 6-7 hrs. After the completion of the reaction, as indicated by TLC examination, the hot solution was poured onto crushed ice followed by basification with ammonia. The product (7a-j) precipitated out during stirring for $10 \mathrm{~min}$. The product was filtered and washed with cold water followed by recrystallization from $\mathrm{MeOH}$.

Microwave reactions (Method B): Thus obtained pure sample of 1,3-cyclohexadiene derivative (6a-j) in the amount of $0.01 \mathrm{~mol}$ was dis-solved in $10 \mathrm{ml}$ of formamide and the solution was adsorbed on $20 \mathrm{gm}$ of acidic alumina or montmoril-lonite $\mathrm{K}_{10}$ clay or silica gel in a small beaker. The reaction mixture was dried in air and the beaker was put in an alumina bath inside the microwave oven and irradiated for 4-5 min. The progress of the reaction was monitored in every $30 \mathrm{sec}$. The product $(7 \mathrm{a}-\mathrm{j})$ was extracted with $\mathrm{EtOH}(4 \times 10 \mathrm{ml})$ and obtained in the solid state after removal of solvent by distillation under reduced pressure. The prod-uct was recrystallized from $\mathrm{MeOH}$.

\section{Result and Discussion}

Synthesis: Benzoin (1) and malononitrile (2) were condensed on a solid support, either basic alumina or montmorillonite $\mathrm{K}_{10}$ clay or silica gel, under microwave irradia-tion to afford 2-amino-3-cyano-4,5-diphenylfuran (3) in good yield. This is a modification of a literature method. Precursor (3) was treated with a $\hat{a}$-unsaturated ketone (4a-j) under microwave irradiations to afford a 1,3-cyclohexadiene deriva-tive (6a-j) via an intermediate (5a-j) after a short reaction time in high yield. The 1,3-cyclohexadiene derivatives were then cyclised with formamide on an acidic alumina solid support under microwave irradiation to obtain 3, 4dihydroben-zo [2, 3-d]pyrimidine derivatives (7a-j) (Scheme 1). The use of acetic acid, hydro-chloric acid, and formic acid employed in the literature method for the conversion of (6a-j) into (7a-j) is avoided in the presented procedure. Only 4-5 min was re-quired for completion of the reaction in $87 \%$ yield by the present method as compared to 6-7 hrs reaction time with $65 \%$ yield by the literature method (Table 1). These observations demonstrate that this method is an expeditious, facile and envi-ronmentally benign one for organic synthesis. 
A.D. Mishra/Solid-supported Synthesis.........

Table 1. Comparison of reaction time and yield of compounds ( $7 a-j)$

\begin{tabular}{|c|c|c|c|c|c|}
\hline \multirow{2}{*}{ Compd. No } & \multirow{2}{*}{ M. P. $/{ }^{\circ} \mathrm{C}$} & \multicolumn{2}{|c|}{ Reaction time } & \multicolumn{2}{|c|}{ Yield/\% } \\
\hline & & Method A/hrs & Method B/min & Method A & Method B \\
\hline $7 a$ & 157 & 7.0 & 5.0 & 53 & 75 \\
\hline $7 \mathrm{~b}$ & 162 & 6.5 & 4.5 & 54 & 78 \\
\hline 7c & 170 & 6.5 & 4.0 & 57 & 81 \\
\hline $7 d$ & 185 & 6.0 & 4.0 & 65 & 87 \\
\hline $7 e$ & 179 & 6.5 & 4.5 & 60 & 82 \\
\hline $7 f$ & 182 & 7.0 & 5.0 & 52 & 73 \\
\hline $7 g$ & 175 & 6.5 & 4.5 & 63 & 85 \\
\hline $7 \mathrm{~h}$ & 193 & 6.0 & 4.0 & 56 & 79 \\
\hline $7 \mathrm{i}$ & 186 & 6.0 & 4.0 & 58 & 81 \\
\hline $7 \mathrm{j}$ & 180 & 7.0 & 4.5 & 56 & 76 \\
\hline
\end{tabular}

Table 2. Spectral data of the compounds (7a-j)

\begin{tabular}{|c|c|c|}
\hline Compd. No. & IR, v/cm ${ }^{-1}$, & ${ }^{1}$ H NMR, ä /ppm \\
\hline \multirow[t]{3}{*}{$7 \mathrm{a}$} & $1600(\mathrm{C}=\mathrm{N})$ & $4.6(\mathrm{~s}, 1 \mathrm{H}, \mathrm{C}-4)$ \\
\hline & $3350(\mathrm{~N}-\mathrm{H})$ & 7.1-7.2 (m, 20H, Ar-H \& $1 \mathrm{H}$ at C-2) \\
\hline & $2240(\mathrm{C} \equiv \mathrm{N})$ & 11.5 (brs, $1 \mathrm{H}, \mathrm{NH})$ \\
\hline \multirow[t]{3}{*}{$7 \mathrm{~b}$} & $1605(\mathrm{C}=\mathrm{N})$ & $2.3\left(\mathrm{~s}, 3 \mathrm{H}, \mathrm{CH}_{3}\right)$ \\
\hline & $3352(\mathrm{~N}-\mathrm{H})$ & 4.6 (s, 1H, C-4) \\
\hline & $2243(\mathrm{C} \equiv \mathrm{N})$ & $4.7(\mathrm{~s}, 1 \mathrm{H}, \mathrm{C}-4)$ \\
\hline \multirow{4}{*}{ 7c } & $1602(\mathrm{C}=\mathrm{N})$ & $4.0\left(\mathrm{~s}, 3 \mathrm{H}, \mathrm{OCH}_{3}\right)$ \\
\hline & $1002(\mathrm{C}-1 \mathrm{~N})$ & 7.1-7.3(m,19H, Ar-H \& 1H at C-2) \\
\hline & $3350(\mathrm{~N}-\mathrm{H})$ & 11.5 (brs, $1 \mathrm{H}, \mathrm{NH})$ \\
\hline & $2240(\mathrm{C} \equiv \mathrm{N})$ & 7.0-7.4 (m, 19H, Ar-H \& $1 \mathrm{H}$ at $\mathrm{C}-2)$ \\
\hline \multirow[t]{3}{*}{$7 d$} & $1600(\mathrm{C}=\mathrm{N})$ & $\begin{array}{l}11.4 \text { (brs, } 1 \mathrm{H}, \mathrm{NH}) \\
4.7(\mathrm{~s}, 1 \mathrm{H}, \mathrm{C}-4)\end{array}$ \\
\hline & $3348(\mathrm{~N}-\mathrm{H})$ & 7.1-7.4 (m, 19H, Ar-H \& 1H at C-2) \\
\hline & $2242(\mathrm{C} \equiv \mathrm{N})$ & 11.5 (brs, 1H, NH) \\
\hline \multirow[t]{3}{*}{$7 e$} & $1608(\mathrm{C}=\mathrm{N})$ & $4.6(\mathrm{~s}, 1 \mathrm{H}, \mathrm{C}-4)$ \\
\hline & $3355(\mathrm{~N}-\mathrm{H})$ & 7.0-7.3 (m, 19H, Ar-H \& $1 \mathrm{H}$ at C-2) \\
\hline & $2247(\mathrm{C} \equiv \mathrm{N})$ & 11.5 (brs, $1 \mathrm{H}, \mathrm{NH})$ \\
\hline \multirow[t]{3}{*}{$7 \mathrm{f}$} & $1610(\mathrm{C}=\mathrm{N})$ & 4.2 (brs, $1 \mathrm{H}, \mathrm{OH})$ \\
\hline & $3360(\mathrm{~N}-\mathrm{H})$ & $4.7(\mathrm{~s}, 1 \mathrm{H}, \mathrm{C}-4)$ \\
\hline & $2250(\mathrm{C} \equiv \mathrm{N})$ & $\begin{array}{l}7.1-7.3(\mathrm{~m}, 19 \mathrm{H}, \mathrm{Ar}-\mathrm{H} \& 1 \mathrm{H} \text { at } \mathrm{C}-2) \\
11.4 \text { (brs. } 1 \mathrm{H} . \mathrm{NH})\end{array}$ \\
\hline \multirow[t]{3}{*}{$7 \mathrm{~g}$} & $1602(\mathrm{C}=\mathrm{N})$ & $4.7(\mathrm{~s}, 1 \mathrm{H}, \mathrm{C}-4)$ \\
\hline & $3345(\mathrm{~N}-\mathrm{H})$ & $7.2-7.8(\mathrm{~m}, 19 \mathrm{H}, \mathrm{Ar}-\mathrm{H} \& 1 \mathrm{H}$ at $\mathrm{C}-2)$ \\
\hline & $2247(\mathrm{C} \equiv \mathrm{N})$ & 11.5 (brs, $1 \mathrm{~N}, \mathrm{NH})$ \\
\hline \multirow[t]{3}{*}{$7 \mathrm{~h}$} & $1612(\mathrm{C}=\mathrm{N})$ & $4.6(\mathrm{~s}, 1 \mathrm{H}, \mathrm{C}-4)$ \\
\hline & 3361(N-H) & $6.4-7.5(\mathrm{~m}, 18 \mathrm{H}, \mathrm{Ar}-\mathrm{H} \& 1 \mathrm{H}$ at $\mathrm{C}-2)$ \\
\hline & $2254(\mathrm{C} \equiv \mathrm{N})$ & 11. 5 (brs, $1 \mathrm{H}, \mathrm{NH})$ \\
\hline \multirow[t]{3}{*}{$7 \mathrm{i}$} & $1615(\mathrm{C}=\mathrm{N})$ & $4.6(\mathrm{~s}, 1 \mathrm{H}, \mathrm{C}-4)$ \\
\hline & $3360(\mathrm{~N}-\mathrm{H})$ & 7.1-7.4(m, $18 \mathrm{H}, \mathrm{Ar}-\mathrm{H} \& 1 \mathrm{H}$ at C-2) \\
\hline & $2255(\mathrm{C} \equiv \mathrm{N})$ & 11.4 (brs, $1 \mathrm{H}, \mathrm{NH})$ \\
\hline \multirow[t]{3}{*}{$7 \mathrm{j}$} & $1605(\mathrm{C}=\mathrm{N})$ & 4.7 (s, 1H, C-4) \\
\hline & $3357(\mathrm{~N}-\mathrm{H})$ & $6.9-8.2(\mathrm{~m}, 20 \mathrm{H}, \mathrm{Ar}-\mathrm{H} \& 1 \mathrm{H}$ at C-2) \\
\hline & $2252(\mathrm{C} \equiv \mathrm{N})$ & 11.5 (brs, $1 \mathrm{H}, \mathrm{NH})$ \\
\hline
\end{tabular}


Table 3. In vitro antibacterial and antifungal activities of compounds (7a-j)

\begin{tabular}{|c|c|c|c|c|c|c|c|}
\hline \multirow[t]{2}{*}{ Compound } & \multicolumn{5}{|c|}{ Bacterial strains } & \multicolumn{2}{|c|}{ Fungal strains } \\
\hline & E. coli & $\begin{array}{l}\text { Rhizobium } \\
\text { japonicum }\end{array}$ & $\begin{array}{l}\text { Enterobactor } \\
\text { aerogenes }\end{array}$ & $\begin{array}{l}\text { Burkholderia } \\
\text { cepacia }\end{array}$ & $\begin{array}{l}\text { Bacillus } \\
\text { mojavensis }\end{array}$ & $\begin{array}{l}\text { Aspergillus } \\
\text { niger }\end{array}$ & $\begin{array}{l}\text { Aspergillus } \\
\text { flavus }\end{array}$ \\
\hline $7 a$ & - & + & + & +++ & - & ++ & +++ \\
\hline $7 \mathrm{~b}$ & - & + & - & + & ++ & ++ & ++ \\
\hline 7c & - & - & + & +++ & + & ++ & +++ \\
\hline $7 d$ & - & + & - & ++ & ++ & ++ & ++ \\
\hline $7 e$ & - & - & - & - & - & - & - \\
\hline $7 f$ & - & - & - & - & - & - & + \\
\hline $7 g$ & - & + & + & ++ & + & + & - \\
\hline $7 \mathrm{~h}$ & - & - & - & + & - & + & + \\
\hline $7 \mathrm{i}$ & - & + & - & - & + & + & + \\
\hline $7 \mathrm{j}$ & - & - & - & - & - & - & - \\
\hline $\begin{array}{l}\text { Oxytetracy } \\
\text { cline*/Salicylic aci }\end{array}$ & $\mathrm{id}^{+*}{ }^{++++}$ & ++++ & ++++ & +++++ & +++++ & ++++ & +++++ \\
\hline
\end{tabular}

*Reference drug in antibacterial screening: -, no measurable activity; +, 2-7 mm; ++, 8-12 mm; +++, 13-17 mm; ++++, 18-22 mm; +++++, 23-26 mm.

**Reference drug in antifungal screening: -, no measurable activity; +, 3-8 mm; ++, 9-13 mm; +++, 14-18 mm; ++++, 19-23mm; +++++, 24-28 mm.

The structures of synthesized 3,4-dihydrobenzo[2.3$d$ ]pyrimidines (7a-j) were ev-idenced from spectral and analytical data. IR absorption band at $1600-1615 \mathrm{~cm}^{-1}$ con-firmed the $(\mathrm{C}=\mathrm{N})$ cyclic linkage in the pyrimidine ring and the band at $2240-2255 \mathrm{~cm}^{-1}$ indicated the presence of a cyano group $(\mathrm{C} \equiv \mathrm{N})$ in the compounds. Moreover, the appear-ance of an IR absorption band at $3345-3360 \mathrm{~cm}^{-1}$ confirmed the presence of a second-ary amino group $(\mathrm{N}-\mathrm{H})$ in the synthesized 3,4dihydrobenzo[2,3-d]pyrimidines (7a-j). The singlet at ä 4.6-4.7 in the ${ }^{1} \mathrm{H}$ NMR spectra was due to the proton at C-4 and the broad singlet at ä 11.4-11.5 was due to the $\mathrm{NH}$ proton in the compounds. All the aromatic protons, including that of furyl, thienyl, pyridinyl substituents, in the synthesized compounds appear at ä 6.4- 8.2 ppm in the ${ }^{1} \mathrm{H}$ NMR spectra (Table 2).

Antifungal and antibacterial activities: 3,4Dihydrobenzo[2,3-d]pyrimidines (7a-j) were tested for their in vitro antifungal activities against Aspergillus niger and Aspergillus flavus by the paper disc diffusion method (Metwali \& Dosoki 2007) and for their in vitro antibacterial activities against E.coli, Rhizobium japonicum, enterobactor aerogenes, Burkholderia cepacia and Bacillus mojavensis by the cup diffusion method (Metwali \& Dosoki 2007). Salicylic acid and oxytetracycline were used as reference drugs in the antifungal and antibacterial screenings respectively. The compounds to be tested were dissolved in dimethyl formamide(DMF) at a concentration of $50 \mathrm{ì} \mathrm{g/ml.} \mathrm{The} \mathrm{inhibition} \mathrm{zone} \mathrm{was}$ measured in millimeters. Among the 3, 4dihydrobenzo[2,3-d]pyrimidines synthesized, 7a-d were found to be moderately active against the mentioned bacteria and fungi (Table 3).

\section{Acknowledgements}

The author offers thanks to the Department of Chemistry, P.N. Campus, for providing available laboratory facilities. The spectral analysis was done in the Instrumental Laboratory, Department of Chemistry, University of Delhi, India, and antimicrobial activities were observed in the Microbiology Laboratory, Janapriya Campus, Pokhara.

\section{References}

Tajudeen, S.S., F.N. Khan. 2007. Benzoin synthesis of heterocycles. Synthetic Communications 37:36493653.

Abdel-galil, E.A., M. Mohamad. 2006. Synthesis of some new pyrimidine derivatives. Bioorganic \& Medicinal Chemistry 14:4341-4348.

Pedro, O. M., M.P. Jose and I.P. Juyan. 2006. Synthesis of bioactive chalcones. Journal of . Medicinal Chemestry, 1:323-329.

Ghorab, M. M., S. G. Abdel-Hamide. 1995. Synthesis of thiopyrimidines. Indian Journal of . Heterocyclic Chemistry 5:115-121. 
A.D. Mishra/Solid-supported Synthesis...

Reddy, P. S., N. T. Vasantha and V. C. Naga. 1999. Biological screening of pyrroles and thioles. Indian Journal Chemistry 38B: 40-46.

Ratham, J. F., T. L. Sleevi and M. C. Campbell. 1990. An expeditious synthesis of azoles. Journal of Medicinal Chemistry 33:161-171.

Vyas, D.H., S.D. Tala and M.P. Dhaduk. 2007. A facile synthesis of furan derivatives. Indian Journal of Chemistry 46B:321-325.

Kumar, A., R. S. Verma and B. P. Sinha. 1990. Solvent free synthesis of lactones. Journal of Indian Chemical . Society 67:920-928.

Sarvanan, J., S. Mohan and K.S. Manjunatha.1998. Cyclisation of unsaturated ketones. Indian Journal of Heterocyclic Chemistry 8:55-61.

Landure, C., D.Deniaud and M. Evain. 2002. Synthesis of chemotherapeutic heterocycles. Journal of Chemical Society, Perkin Trance 1:741-746.

Nair, M. G., R. L. Nanavati, Y. Kusliuk and M. C. Gaumont. 1986. Isolation and characterization of black cumin compounds, Journal of Medicinal Chemistry 29: 1754-1762.

Gamal El-Hiti, A., F. Mohamed Abdel-Megeed and A. G. Yehia Mahmoud. 2000. Biological screening of anthraquinone derivatives. Indian journal of Chemistry 39B:368-376.

Dong,H.S. and G.L. Weik. 2000. Isolation of pyrimidines from lavender. Journal of Chinese Chemical . Society 47:343-349.
Berman, E.M., L. M. Werbel. 1991. Synthesis of unsaturated ketones. Journal of Medicinal Chemistry 34:479-484.

Smith, K., A. Ganiol EI-Hiti and F. Mohamed Abdel-Megeed. 1996. A new synthetic route to thiazoles. Journal of Organic Chemistry 61:647-653.

Archana, P. R., V. K. Srivastava and A. Kumar. 2002. Microwave synthesis of pyrrolopyrimidines. Indian Journal of . Chemistry 41B:2642-2649.

Caddick, S. 1995. Microwave assisted synthesis of heterocycles. Tetrahedron 51:10403-10409

Varma, R. S., R. K. Saini. 1997. Alumina synthesis of heterocycles. Tetrahedron Letters 38: 2623-2630.

Kidwai, M., P. Misra. 1999. Synthesis of bioactive pyrimidines. Synthetic Communications 29: 3237-3243.

Kidwai, M., P. Misra and K. R. Bhushan. 1999. Solid supported synthesis of thiadiazoles. Polyhedron 18: 2641-2645.

Loupy, A., P. Pigeon and H. Ramdani. 1994. Ecofriendly synthesis of oxazoles. Synthetic Communications 24:159-1165.

Moglai, K., G.R. Reddy. 2004. Biological activities of diazoheterocycles. Journal of Chemical Research 10:363-370.

Metwali, M.A., E.I. Dosoki. 2007. Use of thiourea as synthetic precursor. Chemistry of Heterocyclic Compounds 43:469-475. 
Nepal Journal of Science and Technology 11 (2010) 153-158 